\title{
Physiological Aspects of Sun and Shade Leaves of Lithraea molleoides (Vell.) Engl. (Anacardiaceae)
}

\author{
Jaqueline Dias ${ }^{1 *}$, José Antonio Pimenta ${ }^{2}$, Moacyr Eurípedes Medri ${ }^{2}$, Maria Regina Torres \\ Boeger $^{3}$ and Claudinei Toledo de Freitas ${ }^{4}$ \\ ${ }^{1}$ Mestrado em Ciências Biológicas; Centro de Ciências Biológicas; Universidade Estadual de Londrina; \\ jaquedias@vicosa.ufv.br; C. P. 6001; 86051- 970; Londrina- PR - Brasil. ${ }^{2}$ Departamento de Biologia Animal e \\ Vegetal; CCB; C. P. 6001; 86051-970; Londrina - PR - Brasil. ${ }^{3}$ Universidade Federal do Paraná; Setor de \\ Ciências Biológicas; Departamento de Botânica; C. P. 19031; 81531-990; Curitiba - PR - Brasil. ${ }^{4}$ Laboratório de \\ Ecofisiologia; EMBRAPA Soja; C. P. 231; 86001-970; Londrina - PR - Brasil
}

\begin{abstract}
The aim of this work was to compare the physiological parameters of sun and shade leaves of a specimen of $\boldsymbol{L}$. molleoides. The higher-positional leaves, classified as sun leaves, presented similar photosynthetic rate, lower chlorophyill contents $(a, b$ and total), same a chlorophyll $/ b$ chlrorophyll rate, lower transpiratory rate, same stomatal conductance and intercellular concentration of $\mathrm{CO}_{2}$ as the lower-positional leaves, classified as shade leaves. Nutrient concentration, except for $\mathrm{Ca}$ and $\mathrm{Mg}$, was the same for both sun and shade leaves.The physiological parameter responses indicated that although receiving lower light intensity, the shade leaves had the same capacity to grow and develop as the sun leaves.
\end{abstract}

Key words: Photosynthesis, sun leaves, shade leaves, light intensity, chlorophyll, Lithraea molleoides

\section{INTRODUCTION}

In tropical forests, canopy opening, both by anthropic action and natural tree falling, or even canopy closing, produces a condition of light heterogeneity which is morphologically and physiologically reflected in the leaves (Chazdon and Fetcher, 1984; Kira and Yoda, 1989). Tree species are submitted to light variations as evidenced in the higher and lower portion of the same tree (Holbrook and Lund, 1995). Leaf response to different light conditions vary widely among species (Rijkers et al., 2000).

Overall, leaves growing under intense light display the following characteristics: higher mesophyll width, cuticule and photosynthetic rate
(Campostrini et al., 2001; Avalos and Mulkey, 1999; Oguchi et al., 2003). The highest photosynthetic rate in leaves exposed to intense light is associated to important morphoanatomic adaptations, especially greater cuticle and palisade parenchyma thickness, which allow the plant to minimize water loss and transmit the excess of light more directly, under more xeric conditions of the upper portion of the tree crown (Selleck and Shupert, 1957 apud Martinez and Medri, 1985) and to prevent photoinhibition (Lemos-Filho, 2000).

Lithraea molleoides (Vell.) Engl. (Anacardiaceae) is a native phanerogamous species, popularly known as aroeira (aroeira-branca, aroeira-brava, aroeira-do-brejo, aroeirinha, to name a few), 6 to

\footnotetext{
${ }^{*}$ Author for correspondence
} 
$12 \mathrm{~m}$ tall, with a round-like crown. The leaves are composed of altern, imparipinnate, alado-petiolate (Barroso, 1984), 3-11 folioles,5-8 cm long x 1.5$2.5 \mathrm{~cm}$ wide (Lorenzi, 2002). This species occurs in Minas Gerais, São Paulo, Mato Grosso do Sul down to Rio Grande do Sul, under many plant formations.It presents perennefolia, heliophyte and pioneer characteristics and is commonly found in forests located in altitude regions, both in dry and humid terrains.

L. molleoides is found in various types of environment, its investigation being thereby important not only to understand the distinct stages of a tropical forest dynamics but also to certify this species for reforestation of degraded areas. The plants are classified as sun plants and shade plants, depending on their capacity to adjust to differentiated light levels (Boardman, 1977). Such adaptation is directly related to the genotype of each species (Boardman, 1977; Rijkers, 2000). However, crown structure provides distinct environmental conditions to the leaves (Holbrook and Lund, 1995) and differentiated morphoanatomical and physiological characteristics can be noted in leaves developed in the high and low leaves of a same tree (Dale, 1992; Raven et al., 2001).

The objective of this work was to identify the adaptative strategies of a specime of $L$. molleoides under light differences by attempting to find answers to the following questions:

- Is there a difference between the photosynthetic rate of leaves of $L$. molleoides developed under sunlight and under shade?

- Are there differences in chlorophyll content of a, b, and total chlorophyll between the leaves of $L$. molleoides developed in the sunlight and in the shade?

- Are there differences in transpiratory rate, stomatal conductance and intercellular concentration of $\mathrm{CO}_{2}$ between $L$. molleoides leaves developed in the sunlight and in the shade?

- Is there a difference in nutrient concentration between the L. molleoides leaves developed under the sun and in the shade?

\section{MATERIAL AND METHODS}

This study was carried out in a specimen of $L$. molleoides localizated at Ecological Klabin Park, Monte Alegre Farm in Telêmaco Borba - PR - 250 $\mathrm{km}$ from Curitiba-PR, second paranaense highland, mid east region (Fig. 1). The ecological park lies in a vegetational area dominated by Mixed Ombrophila Forest. In particular sites, vegetation is exuberant and composed by species typical of the more advanced successional stages, displayng a floristic richness, probably due to the ecotone zone (Nakajima et al., 1996).

For the physiological studies, ten sun leaves and ten shade leaves were collected from a $L$. moleoides plant. The sun leaves were collected from the peripheral upper portion of the plant and the shade plants from the internal lower portion. In order to determine the photosynthetic rate, stomatal conductance, transpiratory rate and $\mathrm{CO}_{2}$, intercellular concentration were determined on the third foliole on the right, measured from the tip of the leaf toward the base. A portable infrared gas analyzer (A portable gas exchange system (Li6400 (Li-Cor, Lincoln, NE, USA) was used for the evaluations. Light intensity used to evaluate the photosynthetic rate, stomatal conductance, transpiration, and $\mathrm{CO}_{2}$ intercellular concentration was of $1.200 \mu \mathrm{mol} \mathrm{m}^{-2} \mathrm{~s}^{-1}$ selected after elaboration of a saturation curve.

Chlorophyll was quantified in the same leaves used to evaluate the parameters above described. The leaves were washed in deionized water, enclosed in black bags previously labeled and transported in ice from the field to the EmbrapaSoybean Ecophysiology Laboratory in LondrinaPR. Extraction and determination of chlorophyll contents followed the methodology by Arnon (1949), which consist of $80 \%$ acetone extracted, in the dark; the extracts obtained were centrifuged at a rotation of $2500 \mathrm{rpm}$ over 10 minutes and the supernatants placed in $25 \mathrm{ml}$ assay tubes wrapped in aluminum foil , with the volume being completed. The optical density of the substance was measured using a spectrophotometer at 645 and $663 \mathrm{~nm}$. Based on the measurements, chlorophyll concentrations in the solutions were determined by using the formulas below, recommended by Arnon (1949):

Total Chlorophyll $\left(\mathrm{mg} \mathrm{cm}^{-2}\right)=$ [(A645.20.2)+(A663.8.02)].0.025/ area $\left(\mathrm{cm}^{2}\right)$ a Chlorophyll $\left(\mathrm{mg} \mathrm{cm}^{-2}\right)=$ [(12.7. A663 - 2.7.A645).0.025]/ area $\left(\mathrm{cm}^{2}\right)$ b Chlorophyll $\left(\mathrm{mg} \mathrm{cm}^{-2}\right)=$ [(22,9. A645 - 4,7.A663).0,025]/ area $\left(\mathrm{cm}^{2}\right)$. 

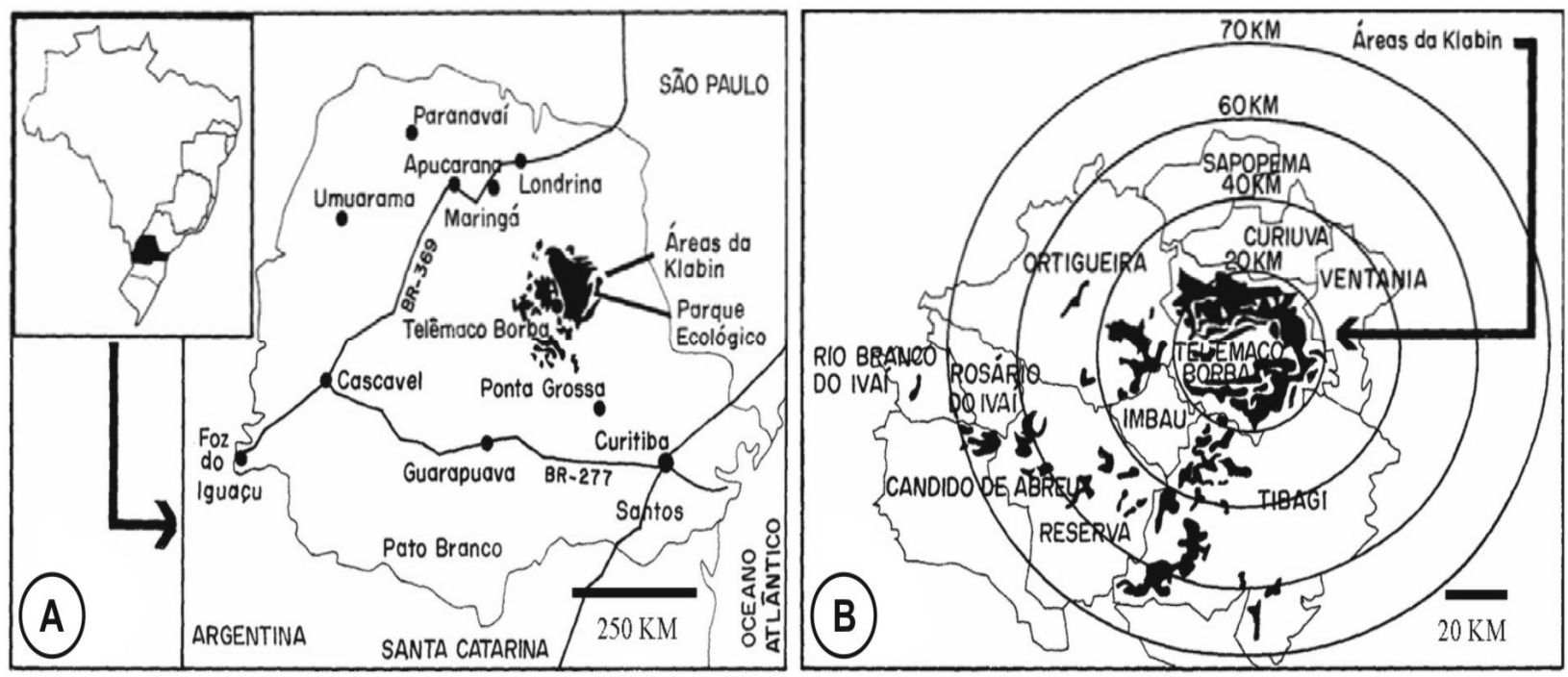

Figure 1 - Location of the Ecological Klabin Park, on Monte Alegre Farm- Telêmaco Borba, PR, where the studied species is found (A). The municípalities comprising Klabin - PR, area are shown in black (B).

To determine the macronutrients $(\mathrm{N}, \mathrm{P}, \mathrm{K}, \mathrm{Ca}$ and $\mathrm{Mg}$ ) and micronutrients ( $\mathrm{Zn}, \mathrm{Mn}, \mathrm{Fe}, \mathrm{Cu}$ and $\mathrm{B})$, the leaves were washed in deionized water, placed into an oven at $60^{\circ} \mathrm{C}$ for 72 , according to the EMBRAPA-Soybean Mineral Analysis Laboratory Methodology. Except for N, the nutrients were quantified in the equipment ICPAES, model Optima 3300 DV. Sample digestion, except for $\mathrm{N}$, was obtained with nitric acid $(6 \mathrm{~N})$ using $0.5 \mathrm{~g}$ of each sample. For nitrogen analysis the equipment Kjeltec, model 1035 Analyser Foss Tecator was used and sample digestion was obtained with sulphuric acid (PA) and hydrogen peroxyde, using $0.1 \mathrm{~g}$ of each sample. Statistical analyses were conducted using Excel program, based on ANOVA (analysis of variance) at a 5\% significance level.

\section{RESULTS AND DISCUSSION}

The photosynthetic rate of the sun leaves of $L$. molleoides was the same as that of the shade leaves (Fig. 2A). The contents of a, b, and total chlorophyll were higher in the shade leaves (Fig. 2B); a chlorophyll / b chlorophyll ratio did not differ in the

leaves developed under the sunlight and shade of L. molleoides (Fig. 2C).
The transpiratory rate of the L. molleoides sun leaves was lower than that of the shade leaves (Fig. 3A). However, stomatal conductance (Fig. 3B) and $\mathrm{CO}_{2}$ intercellular concentration (Fig. 3C) did not differ between leaves developed under sunlight and shade. Sun leaves showed a lower amount of nutrients, except for $\mathrm{Ca}$ and $\mathrm{Mg}$ which were the same, compared to the shade leaves (Table 1).

The non-variation between the photosynthetic rate of sun leaves and shade leaves associated to higher chlorophyll contents in the shade leaves, likely due to a higher amount of photosystems in the membranes of the thylakoid of these leaves (LemosFilho, 2000; Damascos et al., 2006), indicated that shade leaves made an efficient use of the less intense irradiation reaching them. Besides the light effect on the photosynthetic process itself, synthesis and degradation of chlorophylls were also directly associated to light intensity (Engel and Poggiani, 1991). Avalos and Mulkey (1999) studying leaves of Stigmaphyllon lindenianum, Oguchi et al. (2003), leaves of Chenopodium album and Paiva et al. (2003), leaves of Tradescantia pallida, observed considerable changes in response to light differences, both in leaf structure and photosynthetic rate, which increased under greater light conditions. 

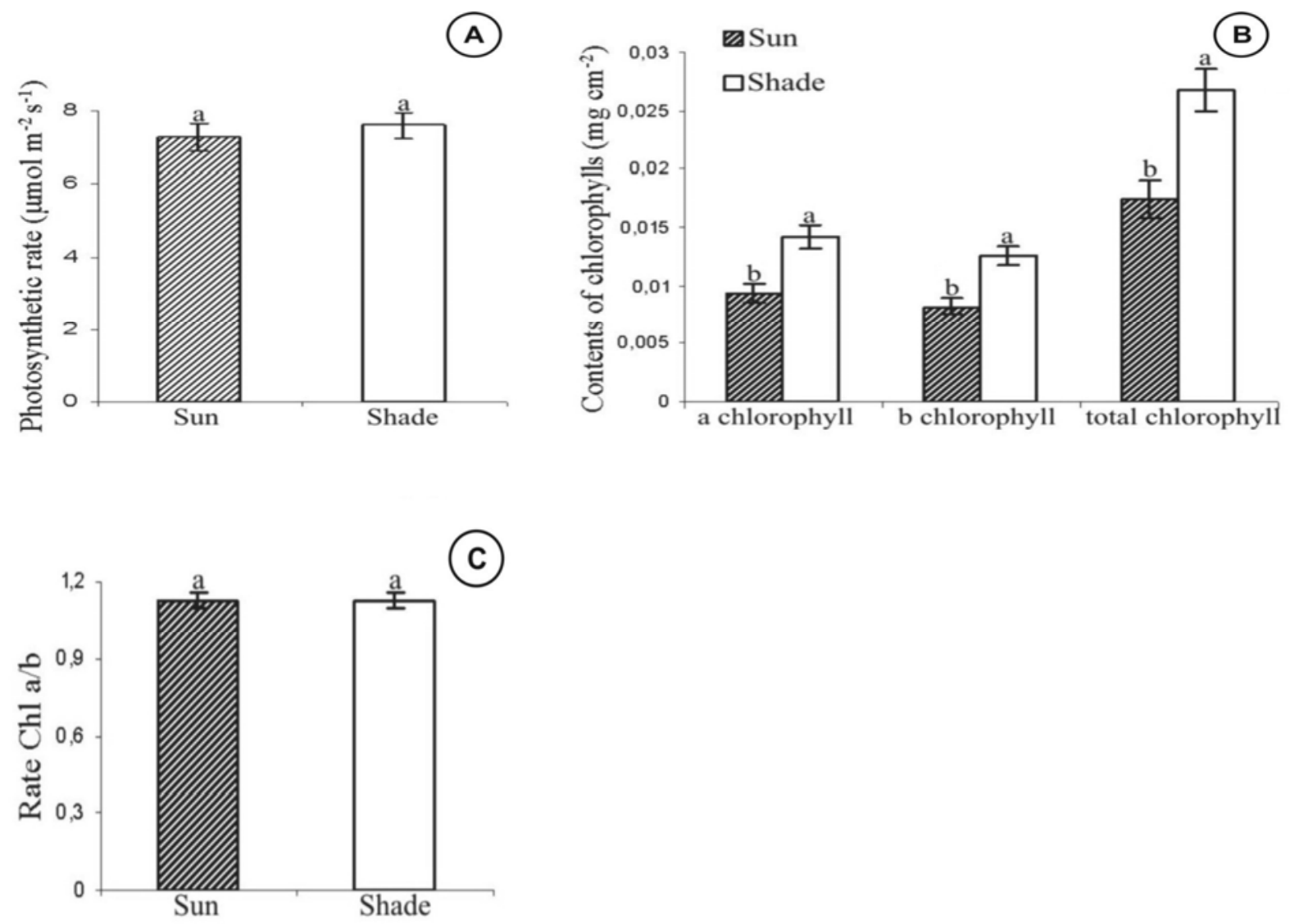

Figure 2 - Photosynthetic rate of Lithraea molleoides leaves developed under sunlight and shade (A). Same letters above the bars did not differ by the F test $(\mathrm{p} \leq 0.05, \mathrm{CV} 15.45 \%)$. Contents of a, b, and total chlorophyll of Lithraea molleoides leaves developed under sunlight and shade (B). Different letters above each pair of bars differed by the $\mathrm{F}$ test ( $\mathrm{p} \leq 0.05$, CV $24.47 \%$ for a chlorophyll, CV $24.24 \%$ for b chlorophyll and CV $24.13 \%$ for total chlorophyll); a chlorophyll / b chlorophyll ratio (a/b Chl Ratio) of Lithraea molleoides leaves developed under sunlight and shade (C). Same letters above the bars did not differ by the F test $(\mathrm{p} \leq 0.05, \mathrm{CV} 8.13 \%)(\mathrm{n}=10)$. The vertical line on the upper part of the bars is the standard error.

Significant leaf structural changes were also identified in L. molleoides (Dias, 2005), but no photosynthetic rate increase was observed in leaves receiving more light. The higher level of chlorophyll in the shade leaves combined with structural change, such as greater intercellular space area of the spongy parenchyma, could be related with the non-differentiation of the photosynthetic rate between sun and shade leaves of L. molleoides (Dias, 2005). Higher chlorophyll contents in shade leaves were also observed by Souza and Válio (2003), studying the changes in leaf optical properties in response to shading on young plants of six tropical tree species of three different successional stages. Such chlorophyll content increase was significant for the determination of tolerant species under shade. Although many studies observed higher chlorophyll contents in shaded leaves than in leaves exposed to greater light (Johnson et al., 1982; Sarracino et al., 1992; Chartzoulakis et al., 1995; Lei and Lechowicz, 1998), some authors did not find any difference among these proportions (Inoue, 1983; Graça, 1983; Kappel and Flore, 1983). 

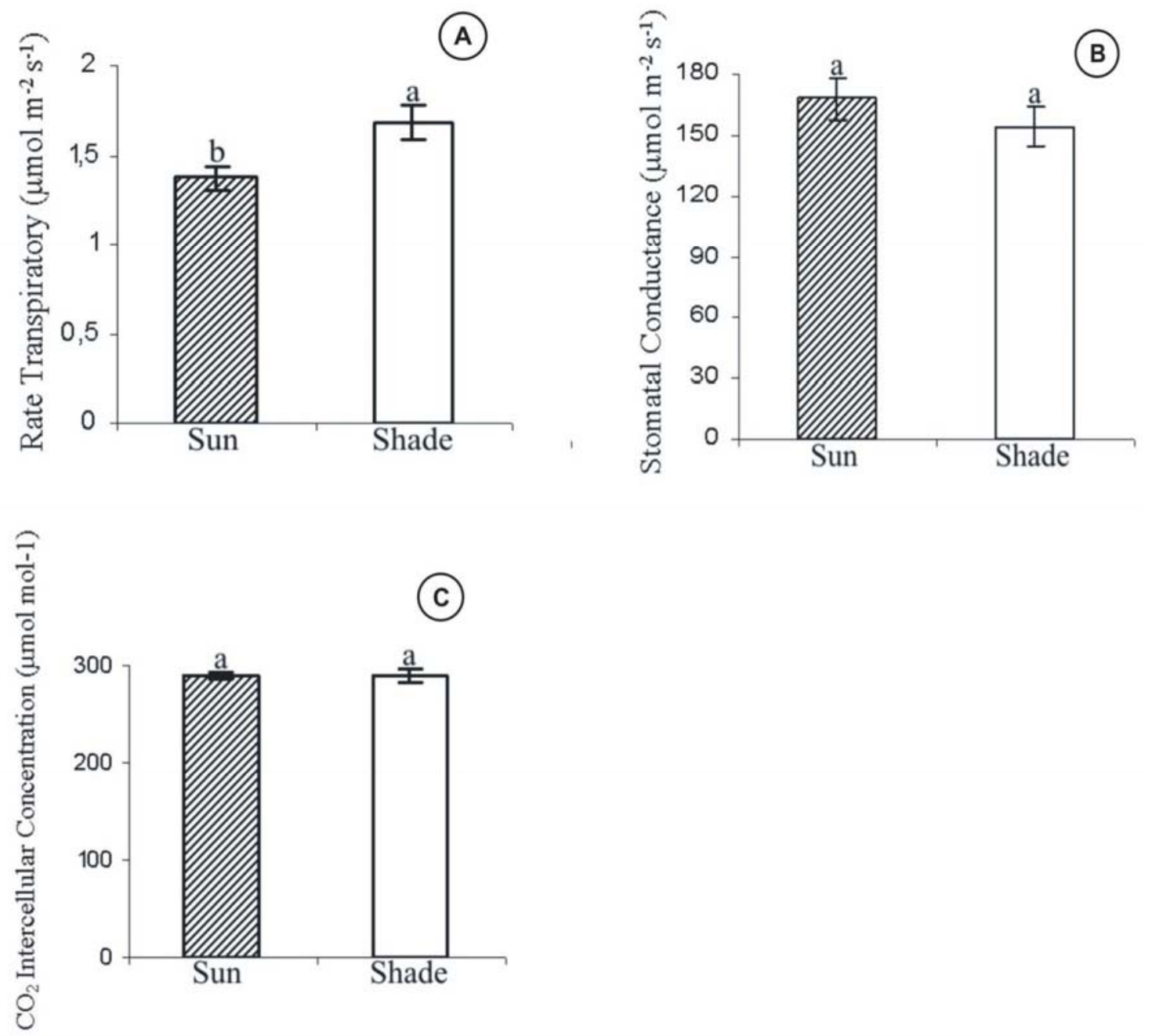

Figure 3 - Transpiration rate of Lithraea molleoides leaves developed under sunlight and shade (A). (CV 16.73\%). Stomatal conductance of Lithraea molleoides d leaves developed under sunlight and shade (B). (CV 19.87\%). $\mathrm{CO}_{2}$ intercellular concentratrion and Lithraea molleoides leaves developed under sunlight and shade (C). (CV 6.32\%) $(n=10)$. Same letters above the bars did not differ by the F test $(\mathrm{p} \leq 0.05)$. The vertical line on the upper part of the bars is the standard error.

Goryshina (1980), Engel and Poggiani (1991) and Atroch et al. (2001) also stressed a higher amount of chlorophyll by chloroplasts in leaves of lowland tropical forest tree species. In addition, several authors reported a higher a chlorophyll/b chlorophyll ratio in sun leaves (Johnson et al., 1982; Chartzoulakis et al., 1995; Lei and Lechowicz, 1998; Souza and Válio, 2003), than in leaves of L. molleoides.

Unaltered a chlorophyll /b chlorophyll ratio in $L$. molleoides was likely due to the fact that this species was a pioneer generally absent in closed places in the forests, since in these places it the occurrence of species displaying leaves with a higher $b$ chlorophyll amount was common to compensate a higher chlorophyll efficiency in absorbing the red wave length reaching the lowland (sub-bosque) (Kozlowski et al., 1991; Atroch et al., 2001; Taiz and Zeiger, 2004). Such adaptation occurs to maintain photosynthesis photochemical phase efficiency (Taiz and Zeiger, 2004).

The L. molleoides leaves developed under shade had a higher transpiratory rate than the leaves developed under sunlight. This fact was not observed by Morais et al. (2003) in study on the 
physiological and growth traits of coffee plants shaded with guandu and cultivated under full sun. This study showed a decrease in leaf transpiration of the shaded coffee plants, likely due to the fact that coffee plants developed under full sun did not present morphoanatomic adaptations sufficiently expressive to transpire less than the leaves developed under shade, as observed in $L$. molleoides.

Table 1 - Concentration of nutrients in Lithraea molleoides leaves developed under sunlight and shade. Averages followed by same letter did not differ by the $\mathrm{F}$ test $(\mathrm{p} \leq 0.05, \mathrm{n}=10)$. The values between parentheses correspond to the standard error.

\begin{tabular}{|c|c|c|c|}
\hline Nutrients & Sun & Shade & CV \\
\hline & \multicolumn{2}{|c|}{$\mathrm{g} 100 \mathrm{~g}^{-1}$} & $\%$ \\
\hline $\mathrm{N}$ & $1.94( \pm 0.058) b$ & $2.44( \pm 0.220) \mathrm{a}$ & 23.19 \\
\hline$P$ & $0.09( \pm 0.002) b$ & $0.11( \pm 0.002) \mathrm{a}$ & 6.84 \\
\hline K & $0.47( \pm 0.020) \mathrm{b}$ & $0.60( \pm 0.020) \mathrm{a}$ & 11.85 \\
\hline $\mathrm{Ca}$ & $0,99( \pm 0.16) \mathrm{a}$ & $1.02( \pm 0.175) \mathrm{a}$ & 38.79 \\
\hline \multirow[t]{2}{*}{$\mathrm{Mg}$} & $0.22( \pm 0.004) \mathrm{a}$ & $0.29( \pm 0.079) \mathrm{a}$ & 5.30 \\
\hline & \multicolumn{2}{|c|}{$\mu \mathrm{g} \mathrm{g}^{-1}$} & \\
\hline $\mathrm{Zn}$ & $9.92( \pm 0.573) b$ & $11.3( \pm 0,260) \mathrm{a}$ & 13.26 \\
\hline $\mathrm{Mn}$ & $87.5( \pm 2.335) b$ & $101.0( \pm 2,206) \mathrm{a}$ & 7.62 \\
\hline $\mathrm{Fe}$ & $62.3( \pm 1.862) b$ & $97.6( \pm 2,235) \mathrm{a}$ & 8.13 \\
\hline $\mathrm{Cu}$ & $4.7( \pm 0.183) \mathrm{b}$ & $5.2( \pm 0,124) \mathrm{a}$ & 9.88 \\
\hline $\mathrm{B}$ & $21.7( \pm 0.592) b$ & $28.4( \pm 0,423) \mathrm{a}$ & 6.49 \\
\hline
\end{tabular}

Stomatal conductance and $\mathrm{CO}_{2}$ intercellular concentration were the same in sun and shade leaves of L. molleoides. This showed that even receiving a higher light intensity, the sun leaves had important morphoanatomic adaptations, allowing the same stomatal conductance and $\mathrm{CO}_{2}$ intercellular concentration of the shade plants, also in agreement with the unchanged photosynthetic rate between the two types of leaves

In Mangifera indica, Castro Neto (2003) observed a lower stomatal conductance in sun leaves in the beginning of the irrigation period (end of May to August), suggesting this to occur due to the end of the water deficit period, since under irrigation, stomatal conductance increase although remaining lower than in the water deficit period. Cruz et al. (2003) observed in the cravo lemmon tree submitted to saline stress, a lower stomatal conductance, with increased salinity content. Sultana et al. (1999) emphasized that a lower leaf stomatal conductance obtained by the plants under saline stress was probably related to the water stress to which these plants were subjected, as the leaves exposed to higher light. A lower stomatal conductance lead to a reduced normal $\mathrm{CO}_{2}$ flux towards the carboxylation site as well as a reduced photosynthetic rate (Xu et al., 1994). L. molleoides sun leaves had lower macronutrient and micronutrient values than the shade leaves, except for macronutrients $\mathrm{Ca}$ and $\mathrm{Mg}$, which did not differ. Since the shade leaves had higher chlorophyll contents than the sun leaves and possibly the same photosynthetic rate in spite of lower light, the results indicated the important role played by most of these nutrients in the photosynthesis process (Clark, 1981; Neves et al., 2004), as they were part of the main molecules involved in the transfer of electrons during the light reactions and also as a source of energy (Taiz and Zeiger, 2004).

Similar Ca levels of the sun and shade leaves were in agreement with the fact that no variations were observed in the stomatal conductance between these two types of leaves (Malavolta, 1997). Both $\mathrm{N}$ and $\mathrm{Mg}$ were part of the chrorophyll molecules; however, when sun and shade leaves of $L$. molleoides, were compared, only $\mathrm{N}$ levels were observed to vary according to the chlorophyll levels, indicating that because these molecules had only one $\mathrm{Mg}$ atom, such variation was not 
sufficient to allow the detection of significant differences in the $\mathrm{Mg}$ levels contrarily to $\mathrm{N}$, as each chlorophyll molecule has four atoms of this element (Majerowicz, 2004).

Leitão and Silva (2004), in a study on seasonal variation of macronutrients in Ouratea spectabilis, a cerrado tree species, observed high contents of nitrogen, phosphorus, potassium, calcium, magnesium and sulphur in the vegetative organs of this species. It was evident that such higher macronutrient contents varied according to the vegetative organs and seasonality, but it was possible to note the efficient use of nutrients by this species, reflecting phenological and distributional patterns, which guarantee its survival in cerrado environments. This showed that the species presented important macronutrient and micronutrient variations based on the environmental conditions.

Neves et al. (2004), in a study on the growth and visual symptoms of micronutrient defficiencies in the umbu tree, a drought adapted species, stressed the importance of the role these micronutrients played in the photosynthetic process. For instance, $\mathrm{Fe}$ participates in enzymatic activation and photosynthesis, playing an important role in the process of biological fixation of $\mathrm{N}$; $\mathrm{Mn}$ also participates in the photosynthesis, acting on the photo chemical release of $\mathrm{O}_{2}$ and $\mathrm{Zn}$ participates mainly in the synthesis of AIA and cellular division (Malavolta et al., 1997).

It was possible that these physiological adaptations associated with the morphoanatomical adaptations of $L$. molleoides allowed the sun leaves higher assimilation of $\mathrm{CO}_{2}$ by moles of transpired water. Besides, the fact that the sun leaves had more chlorophylls and higher nutritional levels allowed them to achieve the same photosynthetic rate as the sun leaves, despite being exposed to lower light. Combined with the morphoanatomical results, the physiological responses of this species showed relative capacity of success of this specime during the first successional forest stages. Such informations are important for the development of projects aiming the recovery of degraded areas.

\section{ACKNOWLEDGMENTS}

The authors are thankful for the financial support provided by PROAP/CAPES to the part of this study, Dr. Alexandre Nepomuceno from
EMBRAPA Soja- Londrina- PR, for the use of the equipments of the Biotechnology and Ecophysiology Laboratory. We also thank technicians of the Ecophysiology Laboratory of EMBRAPA Soja, Claudinei de Freitas Toledo, for the physiological analysis in the field and Nelson Delattre. To the Klabin enterprise representatives, especially the biologist Vlamir José Rocha for allowing us to work at the Klabin Ecological Park (Telêmaco Borba - PR).

\section{RESUMO}

O presente trabalho teve como objetivo avaliar de forma comparativa alguns parâmetros fisiológicos de folhas de sol e de sombra de um espécime de $L$. molleoides. Esta espécie é conhecida popularmente como aroeira-branca. As folhas da porção superior periférica, denominadas folhas de sol, apresentaram igual taxa fotossintética, menores teores de clorofilas ( $\mathrm{a}, \mathrm{b}$ e totais), mesma razão clorofila a/ clorofila $b$, menor taxa transpiratória, mesma condutância estomática e concentração intercelular de $\mathrm{CO}_{2}$ em relação às folhas da porção inferior interna, denominadas folhas de sombra. A concentração de nutrientes, excetuando $\mathrm{Ca}$ e $\mathrm{Mg}$, foi igual em folhas de sol e de sombra. As respostas dos parâmetros fisiológicos avaliados indicam que as folhas de sombra, apesar de receberem menor intensidade luminosa, têm possibilidade de crescer e se desenvolver com a mesma capacidade das folhas de sol.

\section{REFERENCES}

Arnon, D. I. (1949), Cooper enzymes in isolated chloroplasts: poplyphenoloxydase in Beta vulgaris. Plant Physiology, Maryland, 24 : (1), 1-15.

Atroch, E. M. A. C.; Soares, A. M.; Alvarenga, A. A. de e Castro, E. M. de (2001), Crescimento, teor de clorofilas, distribuição de biomassa e características anatômicas de plantas jovens de Bauhinia forficata Link submetidas à diferentes condições de sombreamento. Ciênc. agrotec., 25 : (4), 853-862.

Avalos, G. e Mulkey, S. S. (1999), Photosynthetic acclimation of the liana Stigmaphyllon lindenianum to light changes in a tropical dry forest canopy. Oecologia, 120, 475-484.

Barroso, G. M. (1984), Sistemática de Angiospermas do Brasil. UFV, Viçosa, v.2. pp. 266-267. 
Boardman, N. K.(1977), Comparative photosynthesis of sun and shade plants. Annual Review of Plant Physiology, Palo Alto, 28, 355-377.

Campostrini, E.; Yamanishi, O. K. e Martinez, C. A. (2001), Leaf gas exchange characteristics of four papaya genotypes during different stages of development. Rev. Bras. Frutic., 23: (3), 522-528.

Castro Neto, M. T. de (2003), Efeito do déficit hídrico na transpiração e resistência estomática da mangueira. Rev. Bras. Frutic., 25 : (1), 93-95.

Chartzoulakis, K.; Therios, I. e Noitsakis, B. (1995), Effects of shading on gas exchange specific leaf weight and chlorophyll content in four kiwifruit cultivars under field conditions. Journal of Horticultural Science, Ashford Kent, 68 : (4), 605611.

Chazdon, R. L. e Fetcher, N. (1984), Photosyntetic light environments in a lowland tropical forest in Costa Rica. Journal of Ecology, 72 : 553-564.

Clark, R. B. (1981), Effect of light and water stress on mineral element composition of plants. J. Plant Nut., 3 : (5), 853-885.

Cruz, J. L.; Pelacani, C. R.; Soares Filho, W. dos S.; Castro Neto, M. T. de; Coelho, E. F.; Dias, A. T. e Paes, R. A. (2003), Produção e Partição de matéria seca e abertura estomática do limoeiro "cravo" submetido a estresse salino. Rev. Bras. Frutic., 25 : (3), 528-531.

Dale, J. E. (1992), How do leaves grow? BioScience, 42 : (6), 423-432.

Damascos, M. A.; Ronquim C. C. e Prado, C. H. B. A. (2005), Gas exchange and plant growth after defoliation on Leandra lacunosa, a cerrado Woody species with continuos leaf production. Brazilian Archives of Biology and Technology, 48 : (6), 967974.

Dias, J. (2005), Aspectos morfoanatômicos $e$ fisiológicos de folhas de sol e de sombra de Lithraea molleoides (Vell.) Engl. (Anacardiaceae). Dissertação (Mestrado em Ciências Biológicas). Universidade Estadual de Londrina, Londrina, Paraná, Brasil.

Engel, V. L. e Poggiani, F. (1991), Estudo da concentração de clorofila nas folhas e seu espectro de absorção de luz em função do sombreamento de quatro espécies florestais nativas. Rev. Bras. de Fisiol. Veg., 3: (1), 39-45.

Goryshina, T. K. (1980), Structural and functional features of the leaf assimilatory apparatus in plants of a forest-steppe Oakwood. Geocol. Plant., 1 : (15), 4754.

Graça, M. E. C. (1983), Influence of light intensity on growth nodulation and nitrogen fixation of selected woody actinorhizal species. p. 109 (Philosophy Doctor Thesis) - Purdue University, Purdue.

Holbrook, N. M. e Lund, C. P. (1995), Photosynthesis in forest canopies. In: M. D. Lowman and N. M. Nadkarni, (eds.). Forest Canopies, pp. 430 e 441, Academic Press, California.
Inoue, M. T. (1983), Bases fisiológicas para a silvicultura de espécies nativas. In: INOUE et al. (Ed). A silvicultura de espécies nativas.Fupef, Curitiba. pp. 1-8.

Johnson, C. R.; Nell, T. A. e Rosenbaum, S. E. (1982), Influence of light intensity and drought stress on Ficus benjamina L. Journal of the American Society for Horticultural Science. Mount Vernon, 107 : ( 2), 252-255.

Kappel, F. e Flore, J. A. (1983), Effect of shade on photosynthesis, specific leaf weight clorophyll content of leaves and morphology of young peach trees. Journal of the American Society for Horticultural Science, Mount Vernon, 108 : (3), 541-544.

Kira, T. e Yoda, K. (1989), Vertical stratification in microclimate. Tropical rain forest ecosystems: biogeographical and ecological studies (eds. H. Lieth and M. J. A. Werger). 55-71. Elsevier, Amsterdam.

Kozlowski, T.; Kramer, P. J. e Pallardy, S. G. (1991), The physiological ecology of wood plants. Academic Press, London. p. 657.

Lei, T. T. e Lechowicz, M. J. (1998), Diverse responses of maple saplings to Forest light regimes. Annals of Botany, London, 82 : (1), 9-19.

Leitão, A. C. e Silva, O. A. (2004), Variação sazonal de macronutrientes em uma espécie arbórea de cerrado, na Reserva Biológica e Estação Experimental de Mogi-Guaçu, estado de São Paulo, Brasil. Rodriguésia, 55: (84), 127-136.

Lemos-Filho, J. P. de (2000), Fotoinibição em três espécies do cerrado (Annona crassifolia, Eugenia dysenterica e Campomanesia adamantium) na estação seca e na chuvosa. Rev. Bras. Bot., 23 : (1), 45-50.

Lorenzi, H. (2002), Árvores Brasileiras: Manual de Identificação e Cultivo de Plantas Arbóreas Nativas do Brasil. 4. ed. Plantarum, v. 1, Nova Odessa, p. 20.

Majerowicz, N. (2004), Fotossíntese. In: Kerbauy, G. B. Fisiologia Vegetal. Guanabara Koogan, Rio de Janeiro.

Malavolta, E.; Vitti, G. C. e Oliveira, S. A. (1997), Avaliação do estado nutricional das plantas: princípios e aplicações. Potafos, Piracicaba.

Martinez, M. M. e Medri, M. E. (1985), Alguns aspectos da anatomia-ecológica de Persea americana Mill (abacateiro) e interpretações fisio-ecológicas. Semina, 6 (3):140-146.

Morais, H.; Marur, C. J.; Caramori, P. H.; Ribeiro, A. M. de A. e Gomes, J. C. (2003), Características fisiológicas e de crescimento de cafeeiro sombreado com guandu e cultivado a pleno sol. Pesq. agropec. bras., 38 : (10), 1131-1137. 
Nakajima, J. N.; Soares, L. H.; Medri, M. E.; Goldenberg, R. e Correa, G. T. (1996), Composição florística e fitossociologia do componente arbóreo das florestas ripárias da Bacia do Rio Tibagi: 5. Fazenda Monte Alegre, Município de Telêmaco Borba, Paraná. Arq. Biol. Tecnol., 39 : (4), 933-948.

Neves, O. S. C.; Sá, J. R. de e Carvalho, J. G. de. (2004), Crescimento e sintomas visuais de deficiências de micronutrientes em umbuzeiros. Rev. Bras. Frutic., 26 : (2), 306-309.

Oguchi, R.; Hikosaka, K. e Hirose, T. (2003), Does the photosynthetic light-acclimation need change in leaf anatomy? Blackwell Publishing Ltd, Plant, Cell and Environment, 26 : 505-512.

Paiva, E. A. S.; Isaias, R. M. dos S.; Vale, F. H. A. e Queiroz, C. G. de S. (2003), The influence of light intensity on anatomical structure and pigment contents of Tradescantia pallida (Rose) Hunt. cv. Purpurea Boom (Commelinaceae) Leaves. Brazilian Archieves of Biology and Technology, 46 : (4), 617624.

Raven, P. H.; Evert, R. F. e Eichhorn, S. E. (2001), Biologia Vegetal. 6. ed. Guanabara Koogan, Rio de Janeiro.

Rijkers, T.; Pons, T. L. e Bongers, F. (2000), The effect of tree height and light availability on photosynthetic leaf traits of four neotropical species differing in shade tolerance. Ecological Society, 14 : 77-86.

Souza, R. P. e Válio, I. F. M. (2003), Leaf optical properties as affected by shade in saplings of six tropical tree species differing in successional status. Braz. J. Physiol., 15 : (1), 49-54.
Sarracino, J. H.; Merritt, R. e Chin, C. K. (1992), Morphological and physiological characteristics of Leea coccina rubra in response to light flux. Hortscience, Alexandria, 27 : (5), 400-403.

Sultana, N.; Ikeda, T. e Itoh, R. (1999), Effect of $\mathrm{NaCl}$ salinity on photosynthesis and dry matter accumulation in developing rice grains. Environomental and Experimental Botany, Kidling, 42, 211-220.

Taiz, L. e Zeiger, E. (2004), Fisiologia Vegetal. 3. ed. Artmed, Porto Alegre.

Xu, H. L.; Gauthier, L. e Gosselin, A. (1994), Photosynthetic responses of greenhouse tomato plants to high solution electrical conductivity and low soil water content. Journal of Horticultural Science, 69, 821-832.

Received: June 24, 2005; Revised: February 13, 2006; Accepted: October 16, 2006. 


\section{FOLHA}

EM

BRANCO 